University of Nebraska - Lincoln

DigitalCommons@University of Nebraska - Lincoln

Papers in the Earth and Atmospheric Sciences

Earth and Atmospheric Sciences, Department

2-2005

\title{
The Maastrichtian record from Shatsky Rise (northwest Pacific): A tropical perspective on global ecological and oceanographic changes
}

\author{
Tracy D. Frank \\ University of Nebraska-Lincoln, tfrank2@unl.edu \\ Deborah J. Thomas \\ Texas A\&M University \\ R. Mark Leckie \\ University of Massachusetts, Amherst \\ Michael A. Arthur \\ Pennsylvania State University \\ Paul R. Brown \\ University College London \\ See next page for additional authors \\ Follow this and additional works at: https://digitalcommons.unl.edu/geosciencefacpub \\ Part of the Earth Sciences Commons
}

Frank, Tracy D.; Thomas, Deborah J.; Leckie, R. Mark; Arthur, Michael A.; Brown, Paul R.; Jones, Kelly; and Lees, Jackie A., "The Maastrichtian record from Shatsky Rise (northwest Pacific): A tropical perspective on global ecological and oceanographic changes" (2005). Papers in the Earth and Atmospheric Sciences. 107.

https://digitalcommons.unl.edu/geosciencefacpub/107

This Article is brought to you for free and open access by the Earth and Atmospheric Sciences, Department of at DigitalCommons@University of Nebraska - Lincoln. It has been accepted for inclusion in Papers in the Earth and Atmospheric Sciences by an authorized administrator of DigitalCommons@University of Nebraska - Lincoln. 


\section{Authors}

Tracy D. Frank, Deborah J. Thomas, R. Mark Leckie, Michael A. Arthur, Paul R. Brown, Kelly Jones, and Jackie A. Lees 
Published in Paleoceanography 20 (2005), PA1008; doi: 10.1029/2004PA001052.

Copyright $\odot 2005$ by the American Geophysical Union. Used by permission.

Submitted May 13, 2004; revised October 12, 2004; accepted December 23, 2004; published February 9, 2005.

\title{
The Maastrichtian record from Shatsky Rise (northwest Pacific): A tropical perspective on global ecological and oceanographic changes
}

\author{
Tracy D. Frank, ${ }^{1}$ Deborah J. Thomas, ${ }^{2}$ R. Mark Leckie, ${ }^{3}$ Michael A. Arthur, ${ }^{4}$ \\ Paul R. Bown, ${ }^{5}$ Kelly Jones, ${ }^{5}$ and Jackie A. Lees ${ }^{5}$ \\ 1 Department of Geosciences, University of Nebraska-Lincoln, Lincoln, Nebraska, USA \\ 2 Department of Oceanography, Texas A\&M University, College Station, Texas, USA \\ 3 Department of Geosciences, University of Massachusetts, Amherst, Massachusetts, USA \\ 4 Department of Geosciences, Pennsylvania State University, University Park, Pennsylvania, USA \\ 5 Department of Earth Sciences, University College London, London, UK
}

\section{$\{1\}$ Abstract}

We present new isotopic and micropaleontological data from a depth transect on Shatsky Rise that record the response of the tropical Pacific to global biotic and oceanographic shifts during the mid-Maastrichtian. Results reveal a coupling between the upper ocean, characterized by a weak thermocline and low to intermediate productivity, and intermediate waters. During the earliest Maastrichtian, oxygen and neodymium isotope data suggest a significant contribution of relatively warm intermediate water from the North Pacific. Isotopic shifts through the early Maastrichtian suggest that this warmer water mass was gradually replaced by cooler waters originating in the Southern Ocean. Although the cooler water mass remained dominant through the remainder of the Maastrichtian, it was displaced intermittently at shallow intermediate depths by North Pacific intermediate water. The globally recognized "mid-Maastrichtian event" $\sim 69 \mathrm{Ma}$, manifested by the brief appearance of abundant inoceramid bivalves over shallow portions of Shatsky Rise, is characterized by an abrupt increase $\left(\sim 2^{\circ}-3^{\circ} \mathrm{C}\right)$ in sea surface temperatures, a greater flux of organic matter out of the surface ocean, and warmer $\left(\sim 4^{\circ} \mathrm{C}\right)$ intermediate waters. Results implicate simultaneous changes in surface waters and the sources/ distribution patterns of intermediate water masses as an underlying cause for widespread biotic and oceanographic changes during mid-Maastrichtian time.

\section{Introduction}

\{2\} The recognition of concurrent changes in oceanographic, climatic, and biotic systems several million years before the Cretaceous/Tertiary (K/T) boundary event has led to increased interest in interpreting the Maastrichtian record. This "mid-Maastrichtian event" (MME) encompasses the global extinctions of inoceramid and rudistid bivalves [Johnson and Kauffman, 1996; MacLeod et al., 1996; Chauris et al., 1998], latitudinal migrations of some calcareous nannoplankton and planktic foraminifera [Huber, 1992; Huber and Watkins, 1992], an increase in the rate of global climate cooling [Barrera, 1994; Frank and Arthur, 1999], a decrease in the global range of benthic foraminiferal $\delta^{13} \mathrm{C}$ values, from approximately $3 \%$ o to less than $1 \%$ o [Frank and Arthur, 1999], and an increase in the rate of change of seawater ${ }^{87} \mathrm{Sr} /{ }^{86} \mathrm{Sr}$ isotope ratios [Nelson et al., 1991; Barrera, 1994]. Although there is general agreement that a change in thermohaline circulation patterns played a fundamental role in the $\mathrm{MME}$, the driving mechanism, timing, character, and consequences of the circulation change remain under debate [MacLeod and Huber, 2001].
\{3\} Issues that have complicated understanding of the MME include poor preservation of Maastrichtian carbonate deposited at abyssal paleodepths, sparse sample coverage in the Pacific Ocean, and considerable variability in benthic stable isotope records from different deep-sea sites, reflecting intersite diagenetic variability, differences in the properties of intermediate water masses, or difficulties in correlation between widely separated sites [Barrera and Savin, 1999; Frank and Arthur, 1999]. As a result of these difficulties, two broad, somewhat overlapping, scenarios have arisen regarding the nature of circulation changes associated with the MME, one involving a shift from low-latitude to high-latitude sites of deep water production [MacLeod and Huber, 1996] and the other a transition from North Pacific deep water production to a system dominated by deep-water production in the Southern Ocean and, perhaps, North Atlantic [Barrera and Savin, 1999; Frank and Arthur, 1999]. The suggested triggers include high-latitude cooling and sea level drawdown [MacLeod and Huber, 1996; Barrera et al., 1997], possibly related to glacioeustasy [Barrera and Savin, 1999; Miller et al., 1999, 2003], and changes in the configuration or sill depths of tectonic gateways [Frank and Arthur, 1999]. 

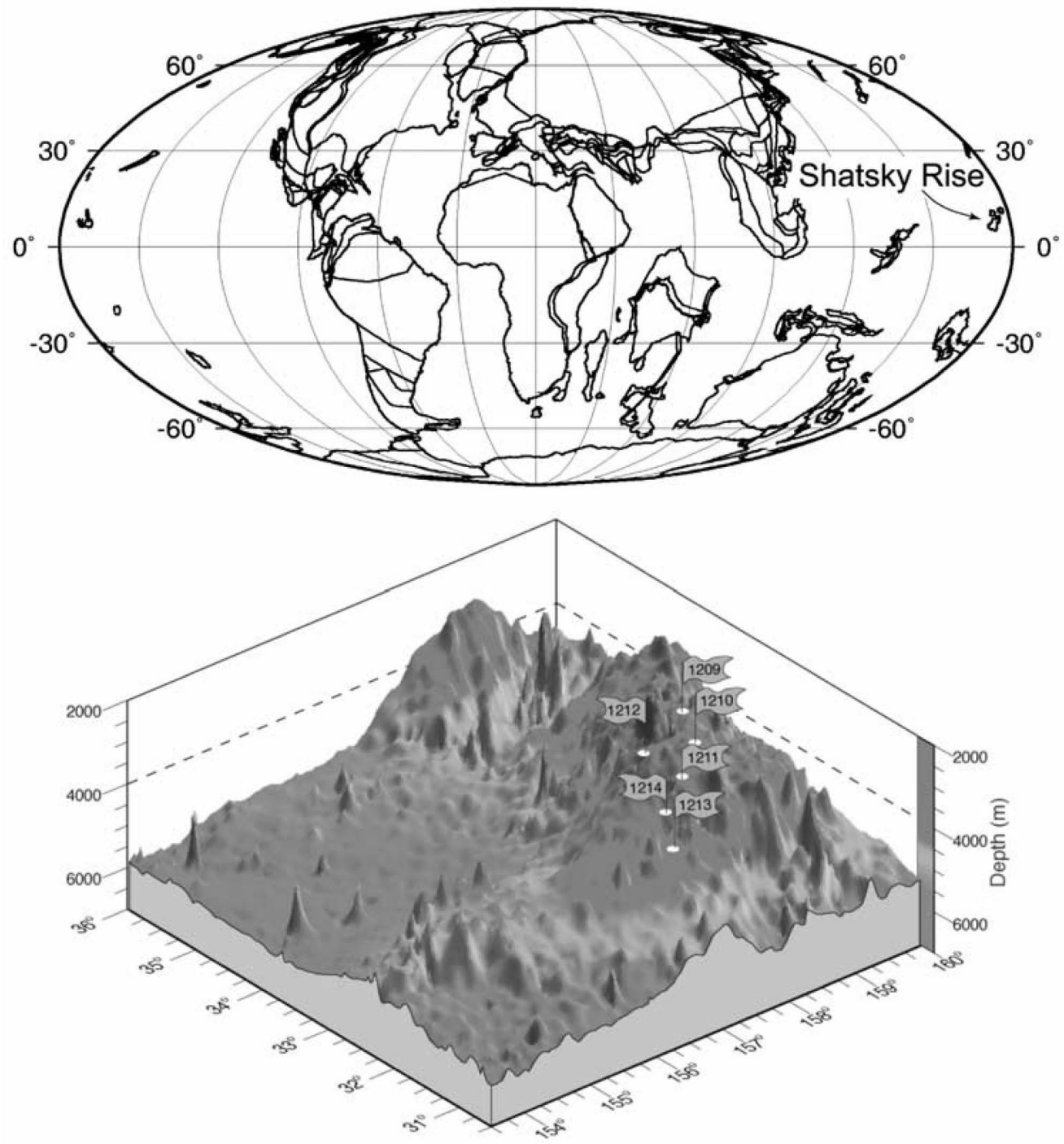

Figure 1. (top) Global reconstruction for $69 \mathrm{Ma}$, showing location of Shatsky Rise in the tropical Pacific. Base map is from the Ocean Drilling Stratigraphic Network (ODSN) Plate Tectonic Reconstruction Service (available at http://www.odsn.de/odsn/services/paleomap/paleomap.html). (bottom) Relief map of Southern High of Shatsky Rise showing locations of ODP Leg 198 drill sites. Modern water depths at Sites 1209, 1210, and 1212 are $2387 \mathrm{~m}, 2573 \mathrm{~m}$, and $2681 \mathrm{~m}$, respectively.

\{4\} Further understanding of circulation changes associated with the MME requires examination of records from diverse deep-sea sites, to elucidate the nature of the transition and how it differs regionally. Given the large aerial extent and, hence, importance of the Pacific Ocean in thermohaline circulation during the Cretaceous, documenting the MME in this basin is critical to understanding this interval of global change. In the present study, multiple proxy records from Ocean Drilling Program (ODP) Sites 1209, 1210, and 1212 on Shatsky Rise (Figure 1) are used to examine the Maastrichtian record of the tropical Pacific. Carbon and oxygen isotope records derived from benthic and planktic foraminiferal calcite are paired with neodymium isotope analyses of fossil fish debris to evaluate changes in the vertical structure of the water column and the sources of water masses that bathed the sites. ${ }^{1}$ Micropaleontological assemblage and isotopic data provide insight into changes in surface water productivity. Comparison with records from sites in other ocean basins is achieved using integrated calcareous microfossil biostratigraphy and ${ }^{87} \mathrm{Sr} /{ }^{86} \mathrm{Sr}$ data that are tied into the magnetostratigraphic timescale of Gradstein et al. [1995].

\{5\} One caveat of this and similar studies arises from the relatively shallow carbonate compensation depth of the latest Cretaceous oceans [Thierstein, 1979; Arthur et al., 1985] and poor preservation of pelagic carbonate at paleodepths exceeding c. $2500 \mathrm{~m}$. Depths less than $2500 \mathrm{~m}$ in the modern oceans are affected by intermediate water masses. Thus, although there were likely

1 Auxiliary isotopic and micropaleontological data are available electronically at World Data Center-A for Paleoclimatology, NOAA/ NGDC, 325 Broadway, Boulder, CO 80303, USA (paleo@mail.ngdc. noaa.gov ; URL: http://www.ncdc.noaa.gov/paleo/data.html ) 
differences in the vertical structure of the latest Cretaceous oceans, benthic records discussed in the present study are most likely recording environmental changes in intermediate, rather than deep, water masses. As such, we refer throughout the paper to bottom waters at Shatsky Rise as intermediate water masses.

\section{Shatsky Rise}

\subsection{Setting}

\{6\} Shatsky Rise, a medium-sized large igneous province in the west central Pacific (Figure 1), formed in Late Jurassic to Early Cretaceous ( 147-135 Ma) time [Nakanishi et al., 1989]. Paleogeographic reconstructions place the Shatsky Rise in tropical latitudes $\left(\sim 10^{\circ} \mathrm{N}\right)$ during the Maastrichtian [Larson et al., 1990]. The stratigraphic distribution of radiolarian chert suggests that Shatsky Rise moved to the northern edge of the equatorial divergence zone by the late Campanian [Bralower et al., 2002]. The Southern High of Shatksy Rise was drilled during three Deep Sea Drilling Project (DSDP) expeditions (Legs 6, 32, and 86), with midMaastrichtian sediments recovered at DSDP Sites 47.2 and 305. Although data from these sites have provided valuable insight into Maastrichtian ocean-climate conditions in the tropical Pacific, the records are somewhat incomplete due to drilling disturbance of unlithified sediment and poor recovery due to the presence of chert. During ODP Leg 198, virtually complete Maastrichtian sections were recovered at four sites (1209-1212) drilled along a depth transect on the Southern High of Shatsky Rise (Figure 1) [Bralower et al., 2002]. Shipboard benthic foraminiferal assemblage data and backtracked paleodepth curves of Kaiho [1999] suggest that during the Maastrichtian these sites lay at upper abyssal (2000-3000 m) water depths.

\subsection{Sedimentology and Stratigraphy}

\{7\} Maastrichtian sediments recovered from the Southern High remain unlithified despite more than $220 \mathrm{~m}$ of sediment overburden at Sites 1209 and 1210. At all sites, the section consists of exceptionally pure ( $\left.>96 \mathrm{wt} \% \mathrm{CaCO}_{3}\right)$, uniform white to pale orange nannofossil ooze containing minor interbeds and nodules of chert [Bralower et al., 2002]. At Sites 1209 (2387 m water depth) and 1210 (2574 m water depth), Maastrichtian strata include a thin, yet prominent, interval with closely spaced layers containing large shells of Inoceramus, a wide ranging benthic bivalve (Figure F24 of Bralower et al. [2002]). Intact inoceramid valves are distinctly more abundant in the upper part of their shortlived stratigraphic range at Shatsky Rise. No inoceramid debris was found outside this "inoceramid event" at Site 1209 (Core 198-1209C-21H-1, 125 cm to 198-1209C-21H-3 cm, 128; 279.15-282.18 m below seafloor (mbsf)). In Hole 1210B, additional prisms were found in a single coarse fraction separate at $261.48 \mathrm{mbsf}$, approximately $1.5 \mathrm{~m}$ above the event interval recognized during shipboard analysis (Core 198-1210B-28H5, $72 \mathrm{~cm}$ to $198-1210 \mathrm{~B}-28 \mathrm{H}-6,52 \mathrm{~cm} ; 262.92-264.22 \mathrm{mbsf}$ ). Although the inoceramid event is absent from Sites 1211 (2907 $\mathrm{m}$ water depth) and 1212 (2681 m water depth), which lie in deeper water, isolated Inoceramus prisms were recov- ered within the same stratigraphic interval. Biostratigraphic data place the inoceramid event within calcareous nannofossil zones CC24-25a (UC18-19) and planktic foraminifer zone KS30, indicating a mid-Maastrichtian age [Gradstein et al., 1995; Burnett, 1999]. This event corresponds to the diachronous global disappearance of Inoceramus at bathyal depths during the mid-Maastrichtian, which has been documented in every ocean basin [MacLeod et al., 1996; Chauris et al., 1998; MacLeod et al., 2000].

\section{Material and Methods}

\subsection{Stable Isotope Analyses}

\{8\} Bulk sediment samples $\left(\sim 10 \mathrm{~cm}^{3}\right)$ from Sites 1209, 1210, and 1212 were disaggregated and washed over a 63 $\mathrm{mm}$ sieve using standard techniques. Coarse fraction residues were examined for microfossil content. Carbon and oxygen isotope analyses of size-sorted separates of clean, well-preserved single foraminiferal species and inoceramid debris were carried out at Pennsylvania State University using an automated carbonate device (common acid bath) coupled to a Finnigan-MAT 252 mass spectrometer. Isotopic ratios were corrected for ${ }^{17} \mathrm{O}$ contribution [Craig, 1957] and are reported in per mil (\%o) relative to the Vienna Peedee belemnite (V-PDB) standard. Precision is better than $0.05 \%$ for $\delta^{13} \mathrm{C}$ and $\delta^{18} \mathrm{O}$ values and was monitored through multiple analyses of National Bureau of Standards (NBS) 19 and other in-house calcite standards.

\subsection{Foraminiferal Preservation and Sample Selection}

\{9\} Diagenetic alteration, often subtle, is a major confounding factor in interpreting oxygen isotope data from foraminiferal calcite [e.g., Douglas and Savin, 1973; Schrag et al., 1995; Pearson et al., 2001; Zachos et al., 2002]. Samples selected for isotopic analysis were clean (devoid of adhering/infilling debris) and appeared well preserved under a standard binocular microscope. Selected samples were observed under the scanning electron microscope (SEM). Results of SEM analysis suggest that foraminifera at Sites 1209,1210 , and 1212 are moderately well to well preserved, with little fragmentation and hollow tests (Figure 2). Although there is evidence of recrystallization in the planktic specimens, consistent compositional differences between benthic and planktic taxa and similarities of isotopic trends among sites despite differences in burial depth suggest that much of the original signal has been preserved.

$\{10\}$ Based on isotopic data from previous studies [e.g., Houston and Huber, 1998; MacLeod et al., 2001; Abramovich et al., 2003], three species of planktic foraminifera, Planoglobulina multicamerata, Globotruncanita stuartiformis, and Rugoglobigerina rugosa, were chosen to allow documentation of changes in productivity and the structure of the upper water column. Carbon isotope data, in particular, indicate that $P$. multicamerata occupied the deepest (thermocline) habitats, living somewhat deeper than G. stuartiformis, and that R. rugosa occupied the mixed layer. Therefore, the difference in isotopic values between $R$. rugosa and $P$. multicamerata was used to determine surface (thermocline-mixed layer) isotopic gradients. Isotopic data from 


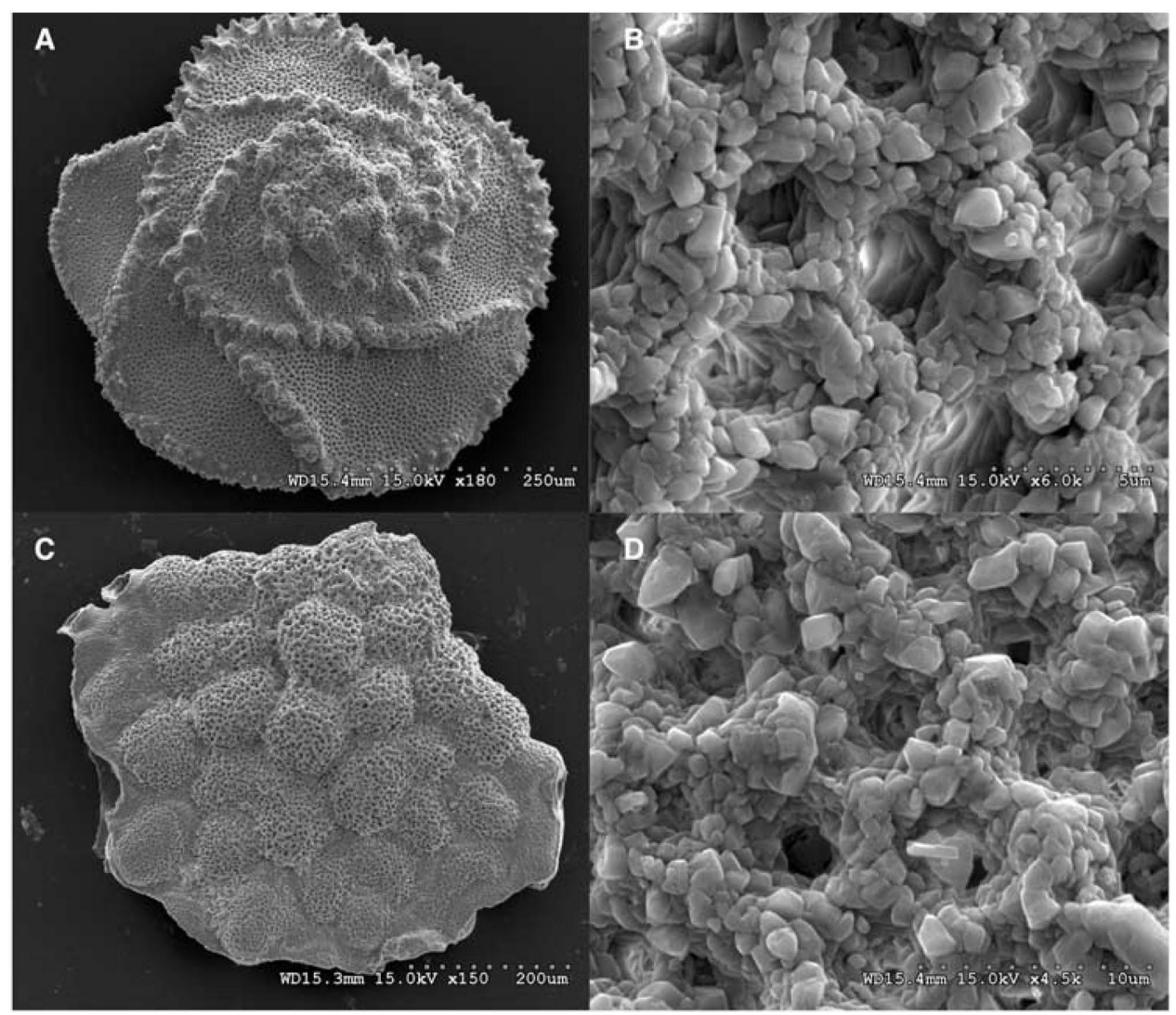

Figure 2. Scanning electron microscope (SEM) images showing whole specimens and details of the planktic foraminifera (a and $\mathbf{b})$ G. stuartiformis and (c and d) P. multicamerata from Shatsky Rise.

G. stuartiformis provided additional information regarding the structure of the upper water column. Due to the paucity of benthic foraminiferal specimens in many samples, two presumed epifaunal taxa, Gavelinella beccariiformis and Nuttallides truempyi, were analyzed to produce a continuous deep-sea benthic isotopic time series.

\subsection{Neodymium Isotope Analyses}

\{11\} Fish debris (teeth and bone fragments) was handpicked from the $>63 \mathrm{~mm}$ size fraction of washed samples, and multiple fragments were used in each $\mathrm{Nd}$ isotope analysis. Samples were cleaned using an intensive reductive/oxidative cleaning protocol [Boyle, 1981; Boyle and Keigwin, 1985], then analyzed as $\mathrm{NdO}^{+}$using a multicollector Micromass Sector 54 at the radiogenic isotope facility at the University of North Carolina-Chapel Hill (UNC). Monitor peak $\left({ }^{144} \mathrm{Nd}^{16} \mathrm{O}\right)$ beams of $\sim 0.5$ to 1 volt were achieved by introducing pure oxygen into the source via a leak valve. External analytical precision based upon replicate analysis of the international JNd standard (as $\mathrm{NdO}^{+}$) [Tanaka et al., 2000] was $0.512109 \pm 0.000007(2 \sigma ; v=24)$. Reported errors reflect within-run precision. Replicate analyses yielded $\mathrm{Nd}$ isotope values within error limits. Results are expressed in epsilon notation, $\varepsilon_{\mathrm{Nd}^{\prime}}$ which normalizes the ${ }^{143} \mathrm{Nd} /{ }^{144} \mathrm{Nd}$ value of a geologic sample to that of the bulk earth where $\varepsilon_{\mathrm{Nd}}=\left(\left({ }^{143} \mathrm{Nd} /{ }^{144} \mathrm{Nd}_{\text {sample }} / 0.512638\right) \times 10,000\right)-1$ [DePaolo and Wasserburg, 1976]. Old continental rocks that contain relatively low Sm concentrations are characterized by low ${ }^{143} \mathrm{Nd} /{ }^{144} \mathrm{Nd}$ values and have very negative, or nonradiogenic, $\varepsilon_{\mathrm{Nd}}$ values. By contrast, younger, mantle-derived rocks have higher initial Sm contents and consequently higher ${ }^{143} \mathrm{Nd} /{ }^{144} \mathrm{Nd}$ values and more radiogenic $\varepsilon_{\mathrm{Nd}}$ values. In the present study $\varepsilon_{\mathrm{Nd}}(\mathrm{t})$ values were calculated assuming a ${ }^{147} \mathrm{Sm} /{ }^{144} \mathrm{Nd}$ value of 0.1310 , the mean value obtained from $10 \mathrm{Sm}$ isotope analyses of Shatsky Rise sediments.

\subsection{Biostratigraphy and Assemblage Analyses}

$\{12\}$ For examination of nannofossil assemblages, samples from Hole 1209C were prepared as simple smear-slides [Bown and Young, 1998]. The first 300 specimens were logged on random fields of view (FOV), and the number of FOV required to reach this figure was noted. Counting was carried out on FOV of approximately equal density to ensure consistency from sample to sample. Count data are plotted as relative abundances. Calcareous nannofossil biostratigraphy is based on the zonal scheme of Sissingh [1977] as modified by Perch-Nielsen [1985] and Burnett [1999].

\{13\} Planktic foraminiferal assemblages from Holes 1209A and $1209 \mathrm{C}$ were based on counts of at least 300 specimens randomly picked from a split of the $>125 \mu \mathrm{m}$ size fraction. Count data are plotted as relative abundances. Additional material was examined to document the first and last occurrence datums (FOs and LOs) of marker taxa. Planktic foraminiferal biostratigraphy is based on the zonal scheme of 
Table 1. Calculated Ages of Selected Markers at Sites 1209, 1211, and $1212^{\mathrm{a}}$

\begin{tabular}{lccc}
\hline Biostratigraphic Datum & $\begin{array}{c}\text { Site 1209 } \\
\text { Age, Ma }\end{array}$ & $\begin{array}{c}\text { Site 1210 } \\
\text { Age, Ma }\end{array}$ & $\begin{array}{c}\text { Site 1212 } \\
\text { Age, Ma }\end{array}$ \\
\hline FO M. murus & $\ldots$ & 67.3 & 67.3 \\
FO A. mayaroensis & 67.9 & 67.3 & $\ldots$ \\
FO R. fructicosa & 68.8 & 68.2 & $\ldots$ \\
FO Z. bicrescenticus & 69.1 & 68.7 & 68.9 \\
LO U. trifidus & $\ldots$ & 70.7 & 71.6 \\
LO Inoceramus & 68.9 & 68.6 & 68.8 \\
FO Inoceramus & 69.2 & 68.8 & 70.5
\end{tabular}

a Anchor points for age model are the $\mathrm{K} / \mathrm{T}$ boundary (65.0 Ma), LO Tranolithus orionatus (69.6 Ma), and FO Contusotruncana contusa (69.6 $\mathrm{Ma})$. Ages of other biostratigraphic datums calculated assuming a constant sedimentation rate.

Caron [1985] and Sliter [1989] with modifications by Premoli Silva and Sliter [1994]. Benthic foraminifera are generally rare in the Maastrichtian ooze of Holes 1209A and 1209C. In most cases the entire $>125 \mu \mathrm{m}$ size fraction was examined and picked completely for benthic specimens, yielding variable population sizes ranging from 24 to 223 specimens.

\subsection{Age Model}

\{14\} The present study applies the Cretaceous timescale of Gradstein et al. [1995] and relies on biostratigraphic data. The anchor points used to generate the age model for Sites 1209, 1210, and 1212 are the K/T boundary (65.0 Ma) and the last occurrence of the calcareous nannofossil Tranolithus orionatus and the first occurrence of the planktic foraminifer Contusotruncana contusa at $\sim 69.6 \mathrm{Ma}$ [Bralower et al., 2002]. Sample ages were calculated assuming a constant rate of sedimentation throughout the examined interval. Calculated sedimentation rates are $11.0 \mathrm{~m} / \mathrm{my}$ at Site $1209,11.3 \mathrm{~m} / \mathrm{my}$ at Site 1210 , and $9.6 \mathrm{~m} / \mathrm{My}$ at Site 1212 . Intersite comparison of the interpolated ages of biostratigraphic datums not used as anchor points (Table 1) indicates that this Maastrichtian age model achieves an intersite resolution of $<0.5$ m.y. for the Southern High of Shatsky Rise. Comparison with records from sites in other ocean basins was accomplished using the correlation scheme applied by Frank and Arthur [1999], in which isotopic, biostratigraphic, and magnetostratigraphic data were tied into the Gradstein et al. [1994] timescale. Note that there is no difference in the Maastrichtian portions of the 1994 and 1995 timescales of Gradstein and others.

\section{Results}

\subsection{Carbon Isotopes}

$\{15\}$ Among the planktic foraminifera examined, the shallow mixed-layer dweller $R$. rugosa is most enriched in ${ }^{13} \mathrm{C}$, followed by G. stuartiformis, and P. multicamerata (Figure 3). At all three sites, the maximum surface water gradient $\left(\delta^{13} C_{\text {Rugoglobigerina rugosa }}-\delta^{13} C_{\text {Planoglobulina multicamerata }}\right)$ of approximately $1 \%$ is observed during the $\sim 1 \mathrm{~m}$.y. leading up to the FO Inoceramus at Sites 1209 (69.2 Ma) and 1210 (68.9 $\mathrm{Ma})$. The remaining portions of the record are characterized by a surface gradient $\leq 0.5 \%$. At Sites 1209 and 1210, simultaneous decreases in $\delta^{13} C_{\text {Rugoglobigerina rugosa }}$ and in- creases in $\delta^{13} C_{\text {Planoglobulina multicamerata }}$ between approximately 69.2 and 68.5 Ma caused the surface water $\delta^{13} \mathrm{C}$ gradient to approach zero during the periods immediately preceding, during, and directly following the inoceramid occurrence at these sites.

$\{16\}$ Through much of the Maastrichtian, benthic $\delta^{13} \mathrm{C}$ values become gradually higher, increasing by $0.5 \%$ at Site 1212 and $1.0 \%$ at Sites 1209 and 1210 (Figure 3). At Site 1209, $\delta^{13} \mathrm{C}_{\mathrm{G}}$. beccariiformis decreases by $\sim 1.5 \%$ o between 66.5 and $66 \mathrm{Ma}$. During the mid-Maastrichtian, the rate of change in benthic $\delta^{13} \mathrm{C}$ values increases temporarily ( $\sim 69.5-69 \mathrm{Ma}$ at Sites 1209 and $1210 ; \sim 70.5-69 \mathrm{Ma}$ at Site 1212). The result is a gradual decrease in the intermediate to surface water $\delta^{13} \mathrm{C}$ gradient.

\subsection{Oxygen Isotopes}

$\{17\}$ Although the expected isotopic ranking is maintained, with $\delta^{18} \mathrm{O}_{P \text {. multicamerata }}>\delta^{18} \mathrm{O}_{G \text {. stuartiformis }}>\delta^{18} \mathrm{O}_{R \text {. ru- }}$ gosa' the surface gradient $\left(\delta^{18} \mathrm{O}_{P . \text { multicamerata }}-\delta^{18} \mathrm{O}_{R \text {. rugosa }}\right)$ remains low, generally $<0.3 \%$, through much of the Maastrichtian (Figure 3). Brief interludes when the surface gradient exceeds $0.5 \%$ are achieved when $\delta^{18} \mathrm{O}_{R \text {. rugosa }}$ exhibits short-lived decreases. These episodes are most evident $\sim 70.5-69.6 \mathrm{Ma}$ (all sites), and at 69.2- 68.5 Ma (Sites 1209 and 1210). The latter interval is coincident with the shortlived inoceramid event.

$\{18\}$ Benthic $\delta^{18} \mathrm{O}$ values increase from a low of $-0.5 \%$ (Sites 1210 and 1212) through the lower Maastrichtian to a maximum of approximately $+0.5 \%$ at $c$. 69 Ma near the beginning of the inoceramid event (Figure 3). Above this interval, benthic $\delta^{18} \mathrm{O}$ values show a long-term decrease, reaching $\sim-0.5 \%$ o by $67 \mathrm{Ma}$. At Site 1209, the long-term decrease in $\delta^{18} \mathrm{O}$ values is followed by an increase to $+1 \%$ o at approximately $66 \mathrm{Ma}$. At the shallowest sites, the gradual decrease in $\delta^{18} \mathrm{O}$ values after $69 \mathrm{Ma}$ is overprinted by higher-order variations between +0.5 and $-0.5 \%$. The longterm decrease in $\delta^{18} \mathrm{O}$ values after $\sim 69 \mathrm{Ma}$ is initiated by a $0.7 \%$ negative excursion that occurs within the upper half of the inoceramid-bearing intervals at Sites 1209 and 1210.

\subsection{Neodymium Isotopes}

$\{19\}$ The Nd isotopic records from Sites 1209 and 1210 exhibit considerable variability (Figure 3). At both sites, average $\varepsilon_{\mathrm{Nd}}$ values lie between -4.0 and -4.5 . Excursions to lower (more negative) values occur at Site 1210 ( 69.7 Ma) and Site 1209 ( 69 Ma, within the upper half of the inoceramid-bearing interval). Values as high as $\varepsilon_{\mathrm{Nd}}-3$ are achieved at Site 1210 ( 71.2 Ma) and at Site 1209, where the record exhibits several fluctuations between $\varepsilon_{\mathrm{Nd}} \sim-5$ and -3 in the interval 68.2-67.5 Ma. The retention of original $\varepsilon_{\mathrm{Nd}}$ values in all samples is suggested by the sharp distinction between $\varepsilon_{\mathrm{Nd}}$ values of Shatsky Rise fish debris $\left(\varepsilon_{\mathrm{Nd}}>-5.27\right)$ and the North Pacific silicate sedimentary fraction $\left(\varepsilon_{\mathrm{Nd}} \mathrm{C}\right.$. -10) [Jones et al., 1994; Pettke et al., 2002], indicating that diagenetic uptake of $\mathrm{Nd}$ was not a factor.

\subsection{Microfossil Assemblages}

\{20\} Samples examined from Hole 1209C yielded abundant, diverse and moderately preserved calcareous nanno- 


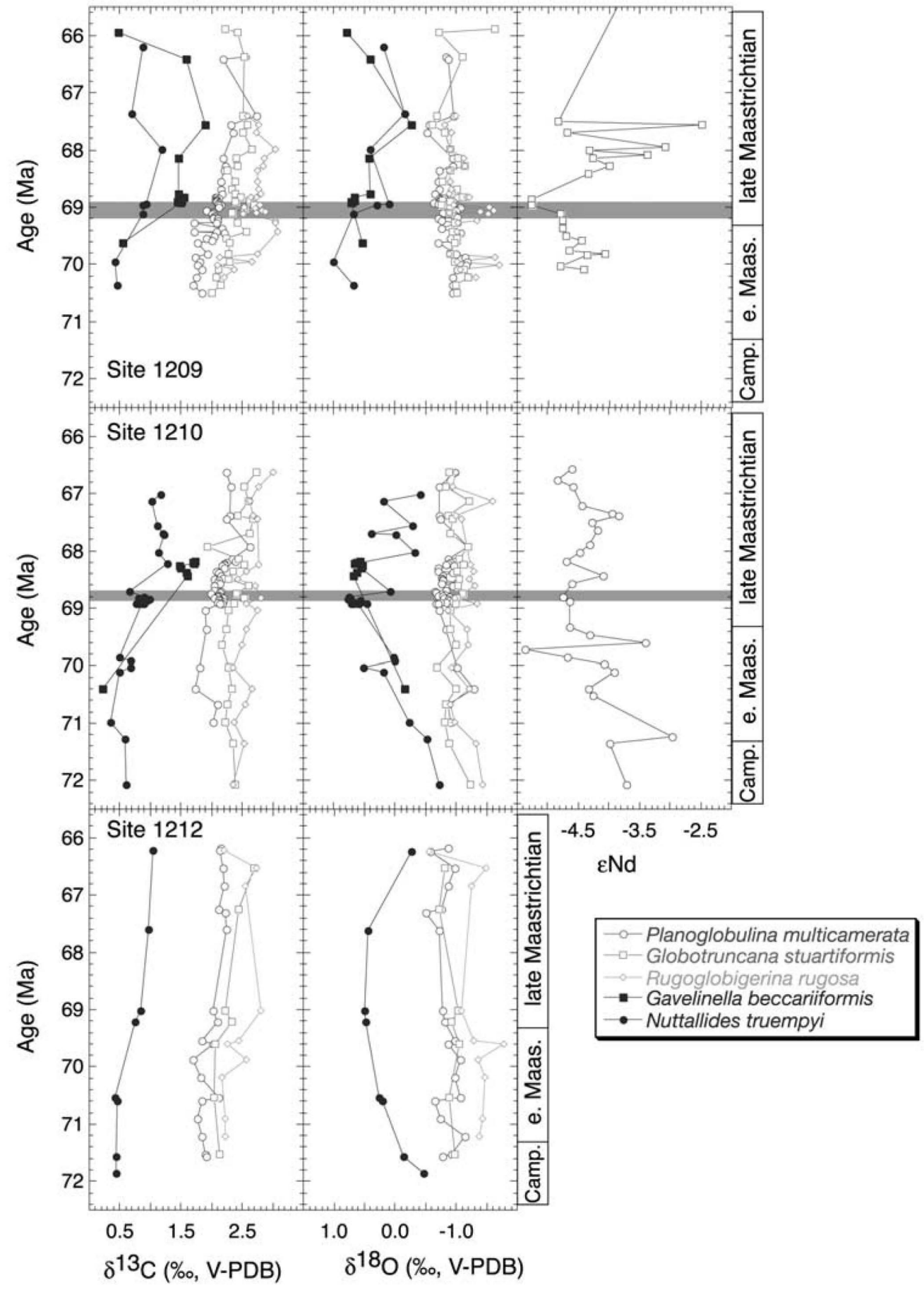

Figure 3. Carbon (left column), oxygen (middle column), and neodymium (right column), isotope records from Sites 1209 (top row), 1210 (middle row), and 1212 (bottom row). Shaded bars across Site 1209 and 1210 records indicate chronostratigraphic extent of the inoceramid event.

fossil assemblages. Preservation does not change significantly through the counted interval, but a moderate degree of overgrowth is ubiquitous. The nannofloras are dominated by the genera Watznaueria and Prediscosphaera, which usually account for 30-60\% of the assemblages (Figure 4); other significant assemblage components (>5\%) include Retecapsa spp., Micula spp., Ceratolithoides spp., Cribrosphaerella spp., Cylindralithus spp., and Tetrapodorhabdus spp.
Most taxon groups show variability on scales ranging from $\sim 20$ to $250 \mathrm{ky}$ (Figure 4).

\{21\} Planktic foraminifera are also moderately abundant to abundant, and moderately well preserved to well preserved with hollow tests and little fragmentation. Benthic foraminifera are rare and constitute $<1 \%$ of the foraminiferal assemblages. Planktic assemblages are dominated by biserial taxa (Heterohelix, Pseudoguembelina, Laeviheterohe- 


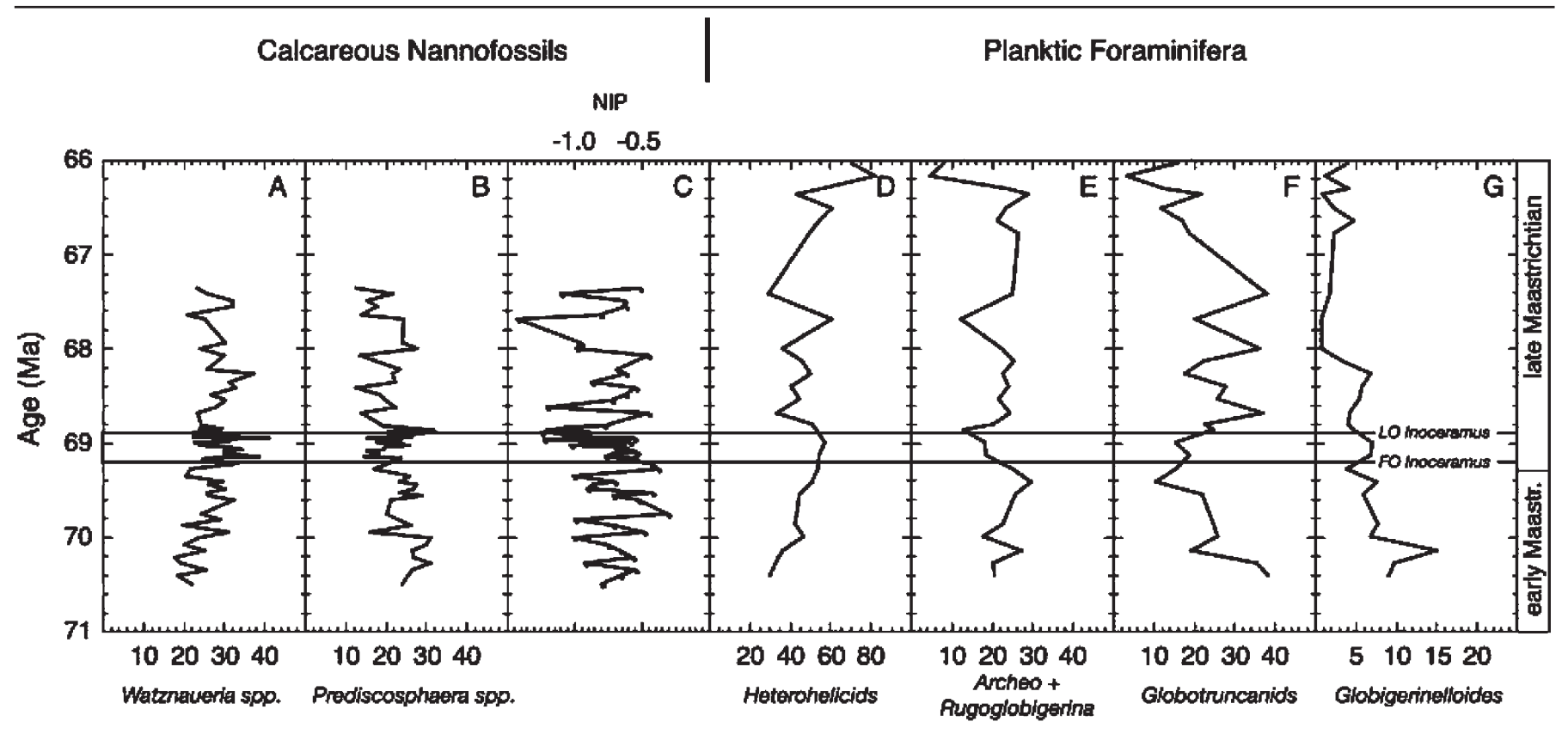

Abundance (\%)

Figure 4. Abundance data for calcareous microfossils (A and B) and planktic foraminifera (D, E, F, and G) at ODP Site 1209. Also shown (C) is the Nannofossil Index of Productivity (NIP) of Eshet and Almogi-Labin [1996], representing the logarithmic ratio between groups of low and high productivity indicators. The NIP value increases with increasing productivity. Note that detailed interpretation of the NIP at Site 1209 is compromised by low abundances of the high productivity taxa of Eshet and Almogi-Labin [1996]. Horizontal lines indicate FO and LO of Inoceramus, which defines the inoceramid event at this site.

lix) with an average value of nearly $50 \%$, whereas multiserial taxa (Racemiguembelina, Planoglobulina, Gublerina) constitute an average of $0.5 \%$ of the assemblages. The relative abundance of biserial taxa varies between $\sim 30 \%$ and $80 \%$, but there are distinct peaks in abundance during the inoceramid interval at Site 1209 and in the post-67 Ma record. The keeled globotruncanids (Globotruncana, Globotruncanita, Rosita, Abathomphalus) constitute an average of $24 \%$ of the assemblages whereas the nonkeeled taxa (Rugoglobigerina, Archeoglobigerina, Hedbergella) average $21.5 \%$. The globotruncanids are most abundant in the interval before 70 $\mathrm{Ma}$ and in the 68.8-67.4 Ma interval immediately following in the inoceramid extinction at Shatsky Rise. The planispiral genus Globigerinelloides makes up an average of $5 \%$ of the assemblages although they display a two-step decline in relative abundance after $70 \mathrm{Ma}$ and again after 68.2 Ma.

\{22\} Benthic foraminiferal assemblages display a high degree of variability that mimics some of the variability observed in the stable isotope and neodymium data. A peak in the abundance of the infaunal buliminids at $70 \mathrm{Ma}$, as well as smaller abundance peaks at $\sim 69.2$ and $68.2 \mathrm{Ma}$ are coincident with marked decreases in $\delta^{18} \mathrm{O}$ values of mixed layer-dwelling $R$. rugosa, suggesting a coupling between changes in the upper water column, such as productivity, and fluctuations in the benthic communities. Benthic foraminiferal assemblages in the interval immediately prior to the inoceramid event at Site 1209 ( 69.9-69.2 Ma) are characterized by Oridorsalis and N. truempyi together with Aragonia or Reussella (a similar assemblage occurs prior to 70
Ma). The inoceramid interval ( 69.2-68.9 Ma) records the virtual disappearance of all of these taxa and the rapid rise of buliminids, numerous small specimens of Neoeponides/ Conorbina, and agglutinated taxa (mostly Gaudryina pyramidata, Recurvoides (?), and Spiroplectammina). An increase in Oridorsalis at the expense of Neoeponides/Conorbina marks the base of the postinoceramid extinction interval followed by assemblages characterized by G. beccariiformis, $N$. truempyi, and Reussella, which dominate until $68 \mathrm{Ma}$.

\section{Discussion}

\subsection{Conditions in the Upper Water Column}

\{23\} Both nannofossil and planktic foraminiferal assemblage data from Site 1209 suggest low- to intermediateproductivity surface waters during the Maastrichtian (Figure 4), consistent with the tropical mid-ocean setting of Shatsky Rise. The nannofossils Watznaueria spp. and Prediscosphaera spp., were chosen as fertility indicators on the basis of work by Eshet and Almogi-Labin [1996], who demonstrated that these taxa belong to nannofossil groups that show affinity for lower (Watznaueria spp.) and higher (Prediscosphaera spp.) productivity conditions. Their Nannofossil Index of Productivity (NIP), the logarithmic ratio between abundances of low and high productivity taxa, is used to infer changes in surface productivity (Figure 4). The high-frequency variability displayed by the data is typical of nannoplankton counts, and may reflect productivity variations on Milankovitch timescales. Within this natural 
range of variability there are no significant above-background abundance events based on these two taxa, suggesting that surface productivity levels remained generally uniform throughout the Maastrichtian. The absence of the putative high-productivity taxa of Eshet and Almogi-Labin [1996] at Site 1209, however, make it difficult to draw firm conclusions about short-term variation in productivity conditions based on the NIP alone.

\{24\} Unlike nannofossil indicators, planktic foraminiferal assemblage data, examined at a coarser scale than for nannoplankton counterparts, show shifts that generally coincide with changes in planktic isotopic records. These excursions suggest that the long-term trend in upper water column conditions, characterized by minimal $\delta^{18} \mathrm{O}$ (temperature) and moderate $\delta^{13} \mathrm{C}$ gradients suggestive of low to intermediate productivity, was overprinted by brief episodes of changing productivity and, possibly, thermal structure. For example at Sites 1209 and 1210 , a short-lived $2^{\circ}-3^{\circ} \mathrm{C}$ warming event (or lower $\delta^{18} \mathrm{O}_{\text {seawater }}$ values), as evidenced by $\delta^{18} \mathrm{O}_{\mathrm{R} \text {. rugosa }}$ coincides with a collapse in the surface $\delta^{13} \mathrm{C}$ gradient $\left(\delta^{93} C_{R \text {. rugosa }}-\delta^{13} C_{P \text {. multicamerata }}\right)$, which in turn coincides with the inoceramid event (Figure 3). One interpretation for the collapse of the surface $\delta^{13} \mathrm{C}$ gradient is that it records higher productivity due to the upwelling of nutrient-rich $\left({ }^{12} \mathrm{C}\right.$-rich) subsurface waters [e.g., Pak and Kennett, 2002]. Changes in planktic foraminiferal assemblages (Figure 4) suggest higher productivity at the time of the inoceramid interval based on the increased relative abundances of heterohelicids (biserial taxa), which are often associated with expansion of oxygen minima [e.g., Leckie et al., 1998; Premoli Silva and Sliter, 1999; MacLeod et al., 2001], and short-lived decreases in the abundance of globotruncanids (keeled taxa), most of which are typical of stratified, oligotrophic waters [e.g., Abramovich et al., 2003]. This interpretation of higher productivity is further supported by the increased abundances of buliminds and small Neoeponides/Conorbina in the benthic assemblages; the former is a group of infaunal taxa that are commonly associated with organic-rich, oxygen-poor conditions at or below the sediment-water interface [e.g., Kaiho, 1994; Jorissen et al., 1995; Bernhard and Sen Gupta, 1999; Jorissen, 1999], while the latter may be analogous to morphologically similar, opportunistic epifaunal taxa of the Cenozoic that respond rapidly to an increased (seasonal) flux of phytodetritus [e.g., Gooday, 1988; Widmark, 1995; Thomas and Gooday, 1996].

$\{25\}$ The difficulty of interpreting the collapse of the surface $\delta^{13} \mathrm{C}$ gradient as being due to increased productivity is that it also coincides with decreases in $\delta^{18} \mathrm{O}_{R \text {. rugosa }}{ }^{\prime}$ possibly recording a $2-3^{\circ} \mathrm{C}$ warming of the near-surface waters, whereas cooling is what is typically expected to occur due to upwelling of subsurface waters [e.g., Pak and Kennett, 2002]. An alternative explanation for the apparent disparity between the measured $\delta^{18} \mathrm{O}$ and $\delta^{13} \mathrm{C}$ values in $R$. rugosa is that this mixed layer taxon contained photosymbionts [Abramovich et al., 2003], which were expelled as a consequence of the warmer sea surface temperatures, analogous to coral bleaching today. Abramovich et al. [2003] suggested that photosymbiotic activity in a number of different Maastrichtian planktic foraminiferal taxa varied from place to place and may not have existed under certain conditions; in other words, some of these taxa may not contain photosymbionts in all locations at all times. Perhaps this is what we observe here as a consequence of a sea surfacewarming event. Evidence from Pacific guyots suggests that contemporaneous sea surface temperatures in the Pacific warm pool were at least as high as those today, if not $\sim 2-$ $5^{\circ} \mathrm{C}$ higher [Wilson and Opdyke, 1996], with higher tropical temperatures perhaps responsible for the demise of associated reef communities [Wilson et al., 1998]. In any case, regardless of whether $R$. rugosa was a part-time photosymbiont-bearing taxon or not, both planktic and benthic foraminiferal data suggest that productivity was somewhat elevated during the brief time of inoceramid presence on the upper reaches of Shatsky Rise.

\{26\} Following the inoceramid extinction, the surface $\delta^{13} \mathrm{C}$ gradient quickly recovered. At the same time, heterohelicids sharply declined in relative abundance while the abundance of globotruncanids increased. These trends indicate a trend toward generally lower surface productivity during the middle to late Maastrichtian. Parallel changes in the composition in benthic foraminiferal assemblages suggest that a different intermediate water mass moved in over Shatsky Rise, or that the flux of organic matter from the surface was different, most likely lower, than during the inoceramid event.

\subsection{Isotopic Constraints on the Origin of Intermediate Water Masses at Shatsky Rise}

$\{27\}$ The stable isotope compositions of benthic foraminifera are used routinely to reconstruct seafloor conditions and thermohaline circulation patterns of the ancient oceans. Such reconstructions rely on the premise that isotopic data from epifaunal benthic foraminifera such as $G$. beccariiformis and $N$. truempyi accurately record the ambient environment in the deep sea [Shackleton et al., 1984; Katz et al., 2003]. Whereas $\delta^{18} \mathrm{O}$ values reflect changes in temperature, salinity, and/or ice volume, $\delta^{13} \mathrm{C}$ values reflect the isotopic composition of dissolved inorganic carbon (DIC).

$\{28\}$ In the modern oceans, DIC in individual water masses becomes progressively enriched in isotopically light $\mathrm{CO}_{2}$ derived from continuous oxidation and remineralization of organic matter as the water mass travels away from its site of formation [Kroopnick, 1985]. This process imparts increasingly negative $\delta^{13} \mathrm{C}$ values on water masses with time and distance as they travel from the site of formation and makes the $\delta^{13} \mathrm{C}$ value of DIC (as recorded in benthic foraminiferal calcite) an effective tracer of thermohaline circulation patterns. This water mass "aging" signal, however, must be interpreted with care, as other processes may affect the isotopic composition of DIC. For example, regions of the seafloor affected by higher biological productivity in overlying surface waters receive a higher flux of particulate organic matter to the seafloor. Degradation of this excess material adds ${ }^{13} \mathrm{C}$-depleted $\mathrm{CO}_{2}$ to the water column, decreasing the $\delta^{13} \mathrm{C}$ value of DIC of the underlying water mass and making it appear older. The isotopic composition of DIC may also be affected by global-scale pro- 


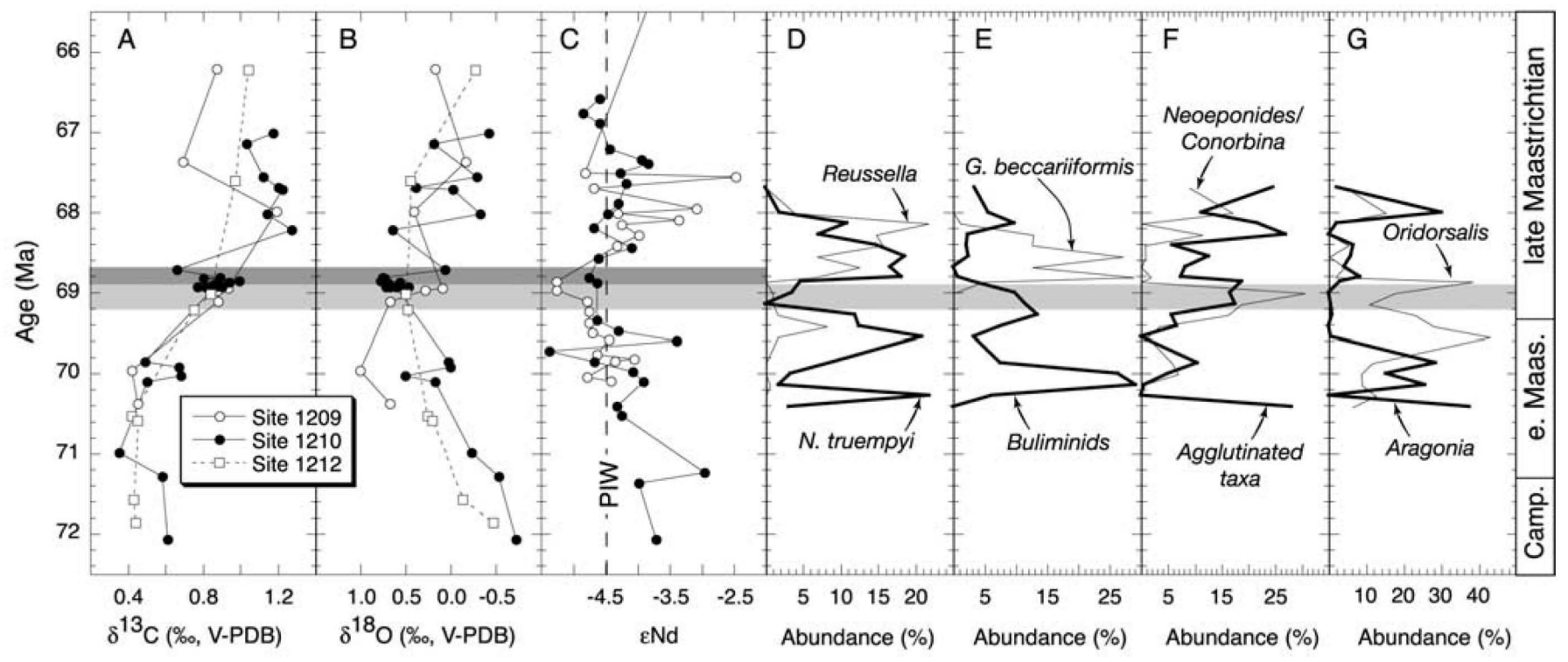

Figure 5. Superimposed benthic carbon (A), oxygen (B), and neodymium (C) isotope records from Sites 1209, 1210 , and 1212 and benthic assemblage data from Site 1209 (D, N. truempyi and Reussella; E, Buliminids and G. beccariiformis; F, agglutinated taxa and Neoeponides/Conorbina; G, Aragonia and Oridorsalis). Carbon and oxygen isotope data are from N. truempyi. Horizontal shaded bars indicate the stratigraphic extent of inoceramid event at Sites 1209 (light) and 1210 (dark). Also indicated is the $\varepsilon_{\mathrm{Nd}}$ value of Pacific Intermediate Water (PIW), formed via mixing of Antarctic Bottom Water $\left(\varepsilon_{\mathrm{Nd}}-8\right)$ and North Pacific Surface Water $\left(\varepsilon_{\mathrm{Nd}} 0\right.$ to -3$)$.

cesses that affect the flux of organic carbon to the oceans.

$\{29\}$ In the present study, neodymium isotope data provide additional constraint on the origin and circulation of intermediate water masses at Shatsky Rise. The ratio of ${ }^{143} \mathrm{Nd} /{ }^{144} \mathrm{Nd}$ in seawater, expressed as $\varepsilon_{\mathrm{Nd}}$ (the ${ }^{143} \mathrm{Nd}$ / ${ }^{144} \mathrm{Nd}$ value of a geologic sample normalized to the bulk earth [DePaolo and Wasserburg, 1976]), is an ideal tracer of oceanic water masses because of the short oceanic residence time of $\mathrm{Nd}$ (c. 1000 years) [Tachikawa et al., 1999] relative to the oceanic mixing rate of $c .1500$ years [Broecker et al., 1960]. The neodymium isotope composition of a given water mass is determined by the general age and composition of the rocks surrounding the source region, giving rise to distinct interbasinal differences in the $\varepsilon_{\mathrm{Nd}}$ values of water masses [Goldstein and Jacobsen, 1987; Elderfield et al., 1990; Halliday et al., 1992; Sholkovitz, 1993].

\{30\} Although data from the Cretaceous are presently scarce, long-term Cenozoic records provide insight into the neodymium isotope compositions of water masses emanating from particular source regions. These records indicate that North Atlantic deep waters have remained the least radiogenic $\left(\varepsilon_{\mathrm{Nd}} \sim<-10\right)$ and Pacific waters the most radiogenic $\left(\varepsilon_{\mathrm{Nd}} \sim-4\right.$ to -5$)$ for the past $\sim 60$ million years [O'Nions et al., 1998]. Indian Ocean deep water and Antarctic Bottom Water (AABW) records indicate that these water masses are characterized by intermediate $\varepsilon_{\mathrm{Nd}}$ values of -8 [Ling et al., 1997]. With an average value of $\varepsilon_{\mathrm{Nd}}-4.5$, the composition of modern Pacific Intermediate Water (PIW) reflects the mixing of AABW with radiogenic surface water from the North Pacific $\left(\varepsilon_{\mathrm{Nd}} 0\right.$ to -3$)$ [Piepgras and Jacobsen, 1988]. The radiogenic composition of surface water in the northern Pacific stems from a weathering contribution from circum-Pacific volcanic arc systems [Goldstein and Jacobsen, 1987]. The long-term subduction histories of the Kula and Farallon Plates around the perimeter of the ancient northern Pacific [e.g., Larson and Pitman, 1972] suggest that the $\varepsilon_{\mathrm{Nd}}$ value of North Pacific surface water has remained unchanged since at least mid-Cretaceous time. The composition of Tethyan seawater has changed significantly over the past $\sim 180$ m.y., from $\varepsilon_{\mathrm{Nd}} \sim-10$ to -6 , due to the effects of changing tectonic configurations and climate on oceanic circulation [Stille et al., 1996]. During the Late Cretaceous, a large influx of Pacific water through the Indian-Tethys seaway is thought to have imparted a more Pacific-like signature, $\varepsilon_{\mathrm{Nd}} \sim-6$ to -8 , to Tethyan seawater.

\{31\} First-order trends in benthic carbon, oxygen, and neodymium isotopic records from Shatsky Rise are similar (Figure 5). By contrast, shorter-term variations differ in terms of magnitude and frequency at each site, and probably reflect variable seafloor conditions at the time of deposition, differences in sampling resolution, and/or disparity in stratigraphic completeness. Through the early Maastrichtian part of the record, first-order trends show rising $\delta^{18} \mathrm{O}$ and $\delta^{13} \mathrm{C}$ values and decreasing $\varepsilon_{\mathrm{Nd}}$ values. The carbon and oxygen isotope trends suggest a growing contribution of cooler, better ventilated and/or younger waters to intermediate depths of the tropical Pacific. The $\varepsilon_{\mathrm{Nd}}$ values (Site 1210), which decrease through this interval from $\varepsilon_{\mathrm{Nd}}-3$ to -3.5 to an average of -4.5 (similar to modern PIW) suggest a change in the source region of intermediate water at Shatsky Rise. 
\{32\} During the latest Campanian and earliest Maastrichtian, warmer bottom temperatures (lower benthic $\delta^{18} \mathrm{O}$ values) and radiogenic $\varepsilon_{\mathrm{Nd}}$ values suggest a significant contribution of intermediate water at Shatsky Rise from the North Pacific. Through the early Maastrichtian, however, isotopic trends indicate that these warmer waters were gradually displaced by cooler waters with a less radiogenic neodymium isotope signature. The formation of modern PIW via mixing of a less-radiogenic water mass originating in the Southern Ocean $\left(\varepsilon_{\mathrm{Nd}}-8\right)$ with North Pacific surface water $\left(\varepsilon_{\mathrm{Nd}} \sim 0\right)$ to produce a neodymium isotopic composition of $\varepsilon_{\mathrm{Nd}}-4.5$ suggests a similar process may have operated during the Maastrichtian.

\{33\} In the latter half of the Maastrichtian record, benthic isotopic trends exhibit greater intersite and intrasite variability (Figure 5). First-order trends show gradually rising $\delta^{13} \mathrm{C}$ values, decreasing $\delta^{18} \mathrm{O}$ values, and $\varepsilon_{\mathrm{Nd}}$ values that average $-4.4 \pm 0.3$ at Site 1210 and oscillate between North Pacific-like and PIW-like values at Site 1209. These long-term changes indicate a return to intermediate water production in the North Pacific in the late Maastrichtian, but with the increased variability in benthic isotopic records suggesting that production was more limited and sporadic than in earlier times. The highly variable nature of oxygen and neodymium isotopic records from Sites 1209 and 1210 suggest that cooler intermediate waters derived from the south were only intermittently displaced by warmer waters from the North Pacific, and that shallower regions of Shatsky Rise were most affected. This is also supported by the benthic foraminiferal assemblage data, which show similar high variability. Relatively uniform $\delta^{13} \mathrm{C}$ and $\delta^{18} \mathrm{O}$ values through this interval at Site 1212 suggest that the warmer water mass was of limited vertical extent and did not penetrate to the depth of Site 1212.

\{34\} This interpretation of benthic isotopic data from Shatsky Rise is consistent with previous reconstructions of global thermohaline circulation patterns during the Maastrichtian. These studies suggested that during the early Maastrichtian intermediate waters formed in the North Pacific and moved southward [Barrera and Savin, 1999], affecting sites in the Southern Ocean before upwelling against tectonic sills that separated the South Atlantic from the Central and North Atlantic basins [Frank and Arthur, 1999]. The mid-Maastrichtian marked a transition to a thermohaline circulation pattern dominated by deep-water production along the Antarctic margin. The cause of the midMaastrichtian circulation change is not well constrained, but has been linked previously to high-latitude cooling and sea level drawdown [MacLeod and Huber, 1996; Barrera et al., 1997], perhaps related to glacioeustasy [Barrera and Savin, 1999], and/or changes in the configuration or sill depths of tectonic gateways [Frank and Arthur, 1999].

\subsection{Significance of Inoceramid Shell Beds}

$\{35\}$ Inoceramid occurrences comprising a series of prominent shell beds over a short stratigraphic interval have been documented at several sites in the central Pacific: ODP Sites 1209, 1210, and DSDP Hole 48.2 (2619 m water depth)
[Heezen et al., 1971] on Shatsky Rise and Hole 465A (2161 m water depth) on the Southern Hess Rise, which lies to the east of Shatsky Rise [Stout et al., 1981]. Biostratigraphic data place all occurrences within the same time interval ( 68.9 Ma at Site 465A, $\sim 68.4 \mathrm{Ma}$ at Site 48.2, and $69.2-68.6$ $\mathrm{Ma}$ at Sites 1209 and 1210), which coincides with the MME and global disappearance of inoceramids $\sim 69 \mathrm{Ma}$. Based on the absence of the inoceramid event at deeper sites on Shatsky Rise, including Site 1212 (2681 m water depth), Site 1211/Site 305 (2907 $\mathrm{m}$ water depth), and DSDP Hole 47.2 (2689 $\mathrm{m}$ water depth), the event appears to have been restricted to the shallower portions of the rise. Their brief appearance suggests that the bivalves responded to the transient development of favorable conditions in these settings by colonizing the rise and then withdrew, or became extinct, when conditions deteriorated.

\{36\} Benthic foraminifera provide insights into the nature of changing seafloor conditions on Shatsky Rise during the mid-Maastrichtian. Benthic foraminifera are known to respond rapidly to changes in the flux of organic matter and/or changing oxygen availability at or below the sediment-water interface [e.g., Corliss, 1985; Jorissen et al., 1995; Jorissen, 1999; Loubere and Fariduddin, 1999; Leckie and Olson, 2003]; fluctuating benthic foraminiferal assemblages at Site 1209 clearly demonstrate that Shatsky Rise experienced changing intermediate water masses and/ or productivity in the overlying surface waters. The inoceramid interval, in particular, is marked by changes at the seafloor and in the surface ocean.

\{37\} Inoceramid bivalves were dominant elements of many benthic communities in the Cretaceous until their extinction $\sim 69 \mathrm{Ma}$. Growing evidence suggests that this extinction event was diachronous [Chauris et al., 1998]. Inoceramid remains are found in a variety of facies ranging from deep to marginal marine, suggesting the bivalves possessed a wide ecological tolerance. A common association with oxygen-restricted facies (e.g., dark, laminated to weakly bioturbated shales), however, suggests that inoceramids favored dysaerobic conditions [e.g., Kauffman, 1981; Kauffman and Sageman, 1988], warm temperatures, low populations of burrowers, an absence of molluscivores [MacLeod, 1994], and/or specific conditions that favored chemosynthetic symbionts [MacLeod and Hoppe, 1992]. It should be noted, however, that inoceramids were rare in shallow water Tethyan environments (E. Kauffman and P. Harries, personal communication, 2004). On the basis of data from the Atlantic, Southern, and Indian oceans, the mid-Maastrichtian south to north diachronous extinction [Chauris et al., 1998] of inoceramids has been attributed to increased oxygenation of the seafloor following a fundamental change in thermohaline circulation [MacLeod, 1994; MacLeod and Huber, 1996].

\{38\} Despite slight differences in timing, inoceramid-bearing horizons at both Sites 1209 and 1210 are associated with sharp decreases in benthic $\delta^{18} \mathrm{O}$ values that suggest a $3-4^{\circ} \mathrm{C}$ warming of seafloor temperatures (Figure 5). At Site 1209, $\varepsilon_{\mathrm{Nd}}$ values drop to a low of -5.3 during the inoceramid interval (Figure 5). Also at Site 1209, a series of high frequency, high amplitude excursions to lower $\delta^{18} \mathrm{O}$ values of $R$. rugosa suggest either short-lived warmings of $\sim 2^{\circ}-3^{\circ} \mathrm{C}$ or decreases 
in salinity in the shallow subsurface (Figure 3). The inoceramid interval is also marked by a collapse in the upper water column $\delta^{13} \mathrm{C}$ gradient between mixed layer $R$. rugosa and thermocline G. stuartiformis and P. multicamerata. Foraminiferal assemblage data suggest that the collapse of the $\delta^{13} \mathrm{C}$ gradient may be due to increased productivity based on increasing relative abundances of the biserial heterohelicids (Figure 4). The direction and magnitude of changes in shallow water biotic proxies do not exceed what is observed at other times during the Maastrichtian, suggesting that environmental changes during the inoceramid interval mainly affected environments below the upper water column. However, the rapid warming of surface waters coincident with the beginning of the inoceramid event at Site 1209 raises the possibility of a causal relationship between the warming event and the anomalous appearance of inoceramids on bathymetric highs of the tropical-subtropical North Pacific. The LO Inoceramus is marked by a shift to cooler bottom and shallow subsurface temperatures, as indicated by increases in benthic and planktic $\delta^{18} \mathrm{O}$ values, a return to PIW-like neodymium isotope signatures, and an increase in the upper water column $\delta^{13} \mathrm{C}$ gradient. These changes suggest a return to conditions similar to those that preceded the inoceramid population of Shatsky Rise.

\{39\} Rapid changes in benthic foraminiferal assemblages and benthic isotopic records suggest that the brief colonization of Shatsky Rise by inoceramids can be explained by a one-time, temporary incursion of a third water mass over shallower portions of the rise, which created a unique set of conditions favorable to the bivalves. A brief warming of sea surface temperatures and perhaps increased productivity during the inoceramid event suggest that the incursion of this water mass was also closely coupled with important changes in the upper water column. Assuming that Pacific inoceramid populations preferred the same conditions as their counterparts in other ocean basins, this water mass would be expected to have been warm, as indicated by benthic $\delta^{18} \mathrm{O}$ values at Site 1209 and 1210. Moreover, because concentrations of dissolved gases decrease with increasing water temperature, this warmer water mass would be expected to be poor in oxygen compared to the cooler water mass that it displaced. Elevated relative abundances of buliminids support this interpretation, while the peak abundances of Neoeponides/Conorbina during the inoceramid event may support an interpretation of increased (seasonal) productivity. Although $\varepsilon_{\mathrm{Nd}}$ values of this water mass (-5.3) do not point toward a definitive source region, one plausible scenario involves the flow of warm, salty waters from regions of the western Tethys (modern Caribbean/Gulf of Mexico) through the Central American Seaway and into the tropical Pacific. Mixing of Tethyan waters possessing a neodymium isotope composition of $\varepsilon_{\mathrm{Nd}} \sim-8$ to -6 [Stille et al., 1996] with Pacific surface waters $\left(\varepsilon_{\mathrm{Nd}} 0\right.$ to -3$)$ could produce a water mass with a composition similar to PIW.

\section{Conclusions}

\{40\} Isotopic and paleontological records from Shatsky Rise reveal that intermediate waters in the tropical Pacific were fed largely by water masses originating in the North Pacific and high latitude Southern Ocean. The benthic oxygen and neodymium isotope records at all three sites suggest that the North Pacific source region, dominant during the late Campanian/earliest Maastrichtian, was gradually displaced as intermediate water production in the Southern Ocean increased through the early Maastrichtian. With the exception of intermittent contributions from the North Pacific after $\sim 68.5 \mathrm{Ma}$, contributions from the Southern Ocean dominated intermediate water at Shatsky Rise throughout the remainder of the Maastrichtian. Lower (more negative) benthic $\varepsilon_{\mathrm{Nd}}$ and $\delta^{18} \mathrm{O}$ values within the inoceramid interval at Sites 1209 and 1210 are attributed to the transient influx of warm saline intermediate waters from the Western Tethys. These changes are accompanied by changes at the sea surface, including an abrupt increase $\left(2-3^{\circ} \mathrm{C}\right)$ in sea surface temperatures and a greater flux of organic matter out of the surface ocean.

\{41\} Data from the present study are at odds with the traditional hypothesis that attributes warm Cretaceous deep waters to sinking of evaporatively concentrated waters in shallow, low-latitude seas [e.g., Chamberlain, 1906; Brass et al., 1982]. More recent simulations of circulation during past warm climate intervals (i.e., Cretaceous, early Cenozoic) suggest that despite differences in tectonic and climatic boundary conditions, deep-water formation involved sinking of high-latitude surface water [e.g., Schmidt and Mysak, 1996; Brady et al., 1998; Bice and Marotzke, 2001; Otto-Bliesner et al., 2002]. Specifically, such simulations predict large overturning cells in both the Northern and Southern hemispheres, with the Southern Hemisphere cell, driven by sinking along the Antarctic margin, tending to dominate. Low-latitude evaporation may have played a role in intermediate water production by "preconditioning" surface waters, once carried poleward by surface gyre currents, for sinking during the winter months [D'Hondt and Arthur, 2002].

\{42\} During the early Maastrichtian at Shatsky Rise, the gradual transition from a larger North Pacific to increasingly dominant Southern Ocean component of intermediate-deep water, as indicated by isotopic records, coincides with evidence for global cooling and falling sea level, possibly related to limited ice buildup in Antarctica [Barrera and Savin, 1999]. Resulting changes in evaporation-precipitation patterns may have caused freshening of the North Pacific due to increased precipitation and continental runoff and, at the same time, increased surface salinities in the southern high latitudes. Episodic contributions from the North Pacific during the late Maastrichtian suggest more rapid fluctuations in precipitation-evaporation patterns (and sites of intermediate water production) during a time of falling sea level and global cooling in the lead up to the early Cenozoic. This circulation pattern, in which intermediate-water production occurred mainly in the Southern Ocean during relatively cool climate intervals and in the North Pacific during intervals of relative warmth, appears to have continued well into the Cenozoic [Thomas, 2004].

\{43\} In the context of the ocean-climate simulations discussed above, the postulated Western Tethyan influence during the time of inoceramid occupation at Shatsky Rise is 
difficult to reconcile. However, the potential for the development of a Mediterranean Intermediate Water-like water mass increases in the context of recent evidence for higher tropical temperatures than at present during the Late Cretaceous [e.g., Pearson et al., 2001], a gradually shrinking Tethys as a consequence of plate tectonic movement, and, possibly, flooding of the shallow Tethyan basin during a period of relatively high sea level between postulated regressions at $\sim 71-69.5 \mathrm{Ma}$ and $\sim 68-67.5 \mathrm{Ma}$ [Barrera and Savin, 1999; Miller et al., 2003]. Such conditions could have combined to produce a shallow, low-latitude seaway in a region prone to production of dense, saline waters via evaporation.

\{44\} Although the present study does not allow identification of the specific trigger responsible for widespread ecological and oceanographic changes $\sim 69 \mathrm{Ma}$, results implicate changes in the source regions and circulation patterns of intermediate water masses as an underlying cause. Understanding the causes and consequences of mid- Maastrichtian changes will require identification of source regions and extents, both vertical and lateral, of intermediate water masses during this period of dynamic biotic and oceanographic change. The present study illustrates the potential of integrating benthic stable and neodymium isotope records in realizing this goal. Multispecies planktic and benthic foraminiferal isotopic analyses coupled with calcareous plankton and benthic foraminiferal assemblage analyses clearly demonstrate that changes in both surface and intermediate waters were responsible for the brief inoceramid interval observed at Shatsky Rise and other elevated areas of the tropical Pacific. These findings provide new insights into the causes for the extinction of inoceramid bivalves $\sim 69$ Ma. Further research will involve high resolution study of the mid-Maastrichtian interval preserved in deep sea cores, particularly along depth transects such as that available on Shatsky Rise, as well as the generation of additional regional geochemical and paleontological records from the Maastrichtian interval as a whole.

\begin{abstract}
Acknowledgments
We are grateful to the drilling operations team, crew, and technicians who sailed on ODP Leg 198 for their assistance and support. We thank Denny Walizer (Biogeochemistry Laboratory, Pennsylvania State University) for stable isotope analyses. RML would like to thank Nick Venti for laboratory assistance. We appreciate the editorial handling efforts of Lisa Sloan and are grateful to reviewers Karen Bice and Paul Wilson for insightful comments that improved the manuscript. Ken MacLeod provided valuable comments on revisions. This research used samples and data provided by ODP, a program sponsored by the U.S. National Science Foundation and participating countries under the management of the Joint Oceanographic Institutions, Inc. Funding was provided by the Australian ODP (T. Frank) and the U.S. Science Support Program (M. Arthur, R.M. Leckie, D. Thomas).
\end{abstract}

\section{References}

Abramovich, S., G. Keller, D. Stuben, and Z. Berner (2003), Characterization of late Campanian and Maastrichtian planktonic foraminiferal depth habitats and vital activities based on stable isotopes, Palaeogeogr. Palaeoclimatol. Palaeoecol., 202, 1-29.

Arthur, M. A., W. E. Dean, and S. O. Schlanger (1985), Variations in the global carbon cycle during the Cretaceous related to cli- mate, volcanism and changes in atmospheric $\mathrm{CO}_{2}$, in The Carbon Cycle and Atmospheric $\mathrm{CO}_{2}$ : Natural Variations Archean to Present, Geophys. Monogr. Ser., vol. 32, edited by E. T. Sundquist and W. S. Broecker, pp. 504-529, AGU, Washington, D. C.

Barrera, E. (1994), Global environmental changes preceding the Cretaceous-Tertiary boundary: Early-Late Maastrichtian transition, Geology, 22, 877-880.

Barrera, E., and S. M. Savin (1999), Evolution of late CampanianMaastrichtian marine climates and oceans, in Evolution of the Cretaceous Ocean-Climate System, edited by E. Barrera and C. Johnson, Spec. Pap. Geol. Soc. Am., 332, 245-282.

Barrera, E., S. M. Savin, E. Thomas, and C. E. Jones (1997), Evidence for thermohaline-circulation reversals controlled by sealevel change in the latest Cretaceous, Geology, 25, 715-718.

Bernhard, J. M., and B. K. Sen Gupta (1999), Foraminifera of oxygen-depleted environments, in Modern Foraminifera, edited by B. K. Sen Gupta, pp. 201-216, Springer, New York.

Bice, K. L., and J. Marotzke (2001), Numerical evidence against reversed thermohaline circulation in the warm Paleocene/Eocene ocean, J. Geophys. Res., 106, 11,519-11,542.

Bown, P. R., and J. R. Young (1998), Techniques, in Calcareous Nannofossil Biostratigraphy, edited by P. R. Bown, pp. 16-28, Springer, New York.

Boyle, E. A. (1981), Cadmium, zinc, copper, and barium in foraminifera tests, Earth Planet. Sci. Lett., 53, 11-35.

Boyle, E. A., and L. D. Keigwin (1985), Comparison of Atlantic and Pacific paleochemical records for the last 250,000 years: Changes in deep ocean circulation and chemical inventories, Earth Planet. Sci. Lett., 76, 135-150.

Brady, E. C., R. M. DeConto, and S. L. Thompson (1998), Deep water formation and poleward ocean heat transport in the warm climate extreme of the Cretaceous (80 Ma), Geophys. Res. Lett., $25,4205-4208$.

Bralower, T. J., et al. (2002), Extreme warmth in the Cretaceous and Paleogene: A depth transect on Shatsky Rise, central Pacific, Proc. Ocean Drill. Program Initial Rep. [CD-ROM], 198.

Brass, G. W., J. R. Southam, and W. H. Peterson (1982), Warm saline bottom water in the ancient ocean, Nature, 296, 620-623.

Broecker, W. S., R. Gerard, M. Ewing, and B. C. Heezen (1960), Natural radiocarbon in the Atlantic Ocean, J. Geophys. Res., 65, 2903-2931.

Burnett, J. A. (1999), Upper Cretaceous, in Calcareous Nannofossil Biostratigraphy, edited by P. R. Bown, pp. 132-199, Chapman and Hall, New York.

Caron, M. (1985), Cretaceous planktic foraminifera, in Plankton Stratigraphy, edited by H. M. Bolli, J. B. Saunders, and K. Perch-Nielsen, pp. 17-86, Cambridge Univ. Press, New York.

Chamberlain, T. C. (1906), On a possible reversal of deep-sea circulation and its influence on geologic climates, J. Geol., 14, 363-373.

Chauris, H., J. LeRousseau, B. Beaudoin, S. Propson, and A. Montanari (1998), Inoceramid extinction in the Gubbio Basin (northeastern Apennines of Italy) and relations with midMaastrichtian environmental changes, Palaeogeogr. Palaeoclimatol. Palaeoecol., 139, 177-193.

Corliss, B. H. (1985), Microhabitats of benthic foraminifera within deep-sea sediments, Nature, 314, 435-438.

Craig, H. (1957), Isotopic standards for carbon and oxygen and correction factors for mass spectrometric analysis of carbon dioxide, Geochim. Cosmochim. Acta, 12, 133-149.

DePaolo, D. J., and G. J. Wasserburg (1976), Nd isotopic variations and petrogenetic models, Geophys. Res. Lett., 3, 248-252.

D'Hondt, S., and M. A. Arthur (2002), Deep water in the late Maastrichtian ocean, Paleoceanography, 17(12), 1008, doi:10.1029/1999PA000486. 
Douglas, R. G., and S. M. Savin (1973), Oxygen and carbon isotope analysis of Cretaceous and Tertiary foraminifera from the central North Pacific, Init. Rep. Deep Sea Drill. Proj., 17, 591-605.

Elderfield, H. R., J. Upstill-Goddard, and E. R. Sholkolvitz (1990), The rare earth elements in rivers, estuaries, and coastal seas and their significance to the composition of ocean waters, Geochim. Cosmochim. Acta, 54, 971-991.

Eshet, Y., and A. Almogi-Labin (1996), Calcareous nannofossils as paleoproductivity indicators in Upper Cretaceous organic-rich sequences in Israel, Mar. Micropaleontol., 29, 37-61.

Frank, T. D., and M. A. Arthur (1999), Tectonic forcings of Maastrictian ocean-climate evolution, Paleoceanography, 14, 103-117.

Goldstein, S. J., and S. B. Jacobsen (1987), The Nd and Sr isotopic systematics of river-water dissolved material: Implications for the sources of $\mathrm{Nd}$ and $\mathrm{Sr}$ in seawater, Chem. Geol., 66, 245-272.

Gooday, A. J. (1988), A response by benthic foraminifera to the deposition of phytodetritus in the deep sea, Nature, 332, 70-73.

Gradstein, F. M., F. P. Agterberg, J. G. Ogg, J. Hardenbol, P. van Veen, J. Thierry, and Z. Huange (1994), A Mesozoic time scale, J. Geophys. Res., 99, 24,501-24,074.

Gradstein, F. M., F. P. Agterberg, J. G. Ogg, J. Hardenbol, P. van Veen, J. Thierry, and Z. Huange (1995), A Triassic, Jurassic and Cretaceous time scale, in Geochronology, Time Scales and Global Stratigraphic Correlation, edited by W. A. Berggren et al., Spec. Publ. SEPM Soc. Sediment. Geol., 54, 95-126.

Halliday, A. N., J. P. Davidson, P. Holden, R. M. Owen, and A. M. Olivarez (1992), Metalliferous sediments and the scavenging residence time of Nd near hydrothermal vents, Geophys. Res. Lett., 19, 761-764.

Heezen, B. C., et al. (1971), Site 48, in Initial Reports of the Deep Sea Drilling Project, vol. 6, edited by A. G. Fischer et al., pp. 145169, U. S. Govt. Print. Off., Washington, D. C.

Houston, R. M., and B. T. Huber (1998), Evidence of photosymbiosis in fossil taxa?: Ontogenetic stable isotope trends in some Late Cretaceous planktonic foraminifera, Mar. Micropaleontol., 34, 29-46.

Huber, B. T. (1992), Paleobiogeography of Campanian-Maastrichtian foraminifers in the southern high latitudes, Palaeogeogr. Palaeoclimatol. Palaeoecol., 92, 325-360.

Huber, B. T., and D. K. Watkins (1992), Biogeography of Campanian-Maastrichtian calcareous plankton in the region of the Southern Ocean: Paleogeographic and paleoclimatic implications, in The Antarctic Paleoenvironment, Antarct. Res. Ser., vol. 56, edited by J. P. Kennett and D. A. Warnke, pp. 31-60, AGU, Washington, D. C.

Johnson, C. C., and E. G. Kauffman (1996), Maastrichtian extinction patterns of Caribbean Province rudistids, in CretaceousTertiary Mass Extinctions: Biotic and Environmental Changes, edited by N. MacLeod and G. Keller, pp. 231-274, W. W. Norton, New York.

Jones, C. E., A. N. Halliday, D. K. Rea, and R. M. Owen (1994), Neodymium isotopic variations in North Pacific modern silicate sediment and the insignificance of detrital REE contributions to seawater, Earth Planet. Sci. Lett., 127, 55-56.

Jorissen, F. J. (1999), Benthic foraminiferal microhabitats below the sediment-water interface, in Modern Foraminifera, edited by B. K. Sen Gupta, pp. 161-179, Springer, New York.

Jorissen, F. J., H. C. de Stigter, and J. G. V. Widmark (1995), A conceptual model explaining benthic foraminiferal microhabitats, Mar. Micropaleontol., 26, 3-15.

Kaiho, K. (1994), Benthic foraminiferal dissolved oxygen index and dissolved oxygen levels in the modern ocean, Geology, 22, 719-722.

Kaiho, K. (1999), Evolution in the test size of deep-sea benthic foraminifera during the past 120 m.y., Mar. Micropaleontol., 44, 291-311.
Katz, M. E., D. R. Katz, J. D. Wright, K. G. Miller, D. K. Pak, N. J. Shackleton, and E. Thomas (2003), Early Cenozoic benthic foraminiferal isotopes: Species reliability and interspecies correction factors, Paleoceanography, 18(2) , 1024, doi:10.1029/2002PA000798.

Kauffman, E. G. (1981), Ecological reappraisal of the German Posidonienschiefer (Toarcian) and the stagnant basin model, in Communities of the Past, edited by J. Gray, A. J. Boucot, and W. B. N. Berry, pp. 311-382, Hutchinson Ross, Stroudsburg, Pa.

Kauffman, E. G., and B. B. Sageman (1988), Biological sensing of benthic environments in dark shales and related oxygen-restricted facies, in Cretaceous Resources, Events and Rhythms: Background and Plans for Research, NATO ASI Ser., Ser. C, vol. 304, edited by R. N. Ginsburg and B. Beaudoin, pp. 121-138, Springer, New York.

Kroopnick, P. M. (1985), The distribution of ${ }^{13} \mathrm{C}$ and $\Sigma \mathrm{CO}_{2}$ in the world oceans, Deep Sea Res., 32, 57-84.

Larson, R. L., and W. C. Pitman III (1972), Worldwide correlation of Mesozoic magnetic anomalies and its implications, Geol. Soc. Am. Bull., 83, 3645-3661.

Larson, R. L., M. B. Steiner, E. Erba, and Y. Lancelot (1990), Paleolatitudes and tectonic reconstructions of the oldest portion of the Pacific Plate: A comparative study, Proc. Ocean Drill. Program Sci. Results, 129, 615-631.

Leckie, R. M., and H. C. Olson (2003), Foraminifera as proxies for sea-level change on siliciclastic margins, in Micropaleontologic Proxies for Sea-Level Change and Stratigraphic Discontinuities, Spec. Publ. SEPM Soc. Sediment. Geol., 75, 5-19.

Leckie, R. M., R. F. Yuretich, O. L. O. West, D. Finkelstein, and M. Schmidt (1998), Paleoceanography of the southwestern Western Interior Sea during the time of the Cenomanian-Turonian boundary (Late Cretaceous), in Stratigraphy and Paleoenvironments of the Cretaceous Western Interior Seaway, USA, SEPM Concepts Sediment. Paleontol., vol. 6, pp. 101-126, Soc. Sediment. Geol., Tulsa, Okla.

Ling, H.-F., K. W. Burton, R. K. O'Nions, B. S. Kamber, F. von Blanckenburg, A. J. Gibb, and J. R. Hein (1997), Evolution of $\mathrm{Nd}$ and $\mathrm{Pb}$ isotopes in central Pacific seawater from ferromanganese crusts, Earth Planet. Sci. Lett., 146, 1-12.

Loubere, P., and M. Fariduddin (1999), Benthic foraminifera and the flux of organic carbon to the seabed, in Modern Foraminifera, edited by B. K. Sen Gupta, pp. 181-199, Springer, New York.

MacLeod, K. G. (1994), Bioturbation, inoceramid extinction and mid-Maastrichtian ecological change, Geology, 22, 139-142.

MacLeod, K. G., and K. A. Hoppe (1992), Evidence that inoceramid bivalves were benthic and harbored chemosynthetic symbionts, Geology, 20, 117-120.

MacLeod, K. G., and B. T. Huber (1996), Reorganization of deep ocean circulation accompanying a Late Cretaceous extinction event, Nature, 380, 422-425.

MacLeod, K. G., and B. T. Huber (2001), The Maastrichtian record at Blake Nose (western North Atlantic) and implications for global palaeoceanographic and biotic changes, in Western North Atlantic Palaeogene and Cretaceous Palaeoceanography, edited by D. Kroon, R. D. Norris, and A. Klaus, Geol. Soc. Spec. Publ., 183, 111-130.

MacLeod, K. G., B. T. Huber, and P. D. Ward (1996), The biostratigraphy and paleobiogeography of Maastrichtian inoceramids, in The Cretaceous-Tertiary Event and Other Catastrophes in Earth History, edited by G. Ryder, D. Fastovsky, and S. Gartner, Spec. Pap. Geol. Soc. Am., 307, 361-373.

MacLeod, K. G., B. T. Huber, and M. L. Ducharme (2000), Paleontological and geochemical constraints on changes in the deep ocean during the Cretaceous greenhouse interval, in Warm Cli- 
mates in Earth History, edited by B. T. Huber, K. G. MacLeod, and S. L. Wing, pp. 241-274, Cambridge Univ. Press, New York.

MacLeod, K. G., B. T. Huber, T. Pletsch, U. Roehl, and M. Kucera (2001), Maastrichtian foraminiferal and paleoceanographic changes on Milankovitch timescales, Paleoceanography, 16, 133-154.

Miller, K. G., E. Barrera, R. K. Olsson, P. J. Sugarman, and S. M. Savin (1999), Does ice drive Maastrichtian eustasy?, Geology, 27, 783-786.

Miller, K. G., P. J. Sugarman, J. V. Browning, M. A. Kominz, J. C. Hernandez, R. K. Olsson, J. D. Wright, M. D. Feigenson, and W. Van Sickel (2003), Late Cretaceous chronology of large, rapid sea-level changes; glacioeustasy during the greenhouse world, Geology, 31, 585-588.

Nakanishi, M., K. Tamaki, and K. Kobayashi (1989), Mesozoic magnetic anomaly lineations and seafloor spreading history of the northwestern Pacific, J. Geophys. Res., 94, 15,437-15,462.

Nelson, B. K., K. G. MacLeod, and P. D. Ward (1991), Rapid change in strontium isotopic composition of seawater before the Cretaceous/ Tertiary boundary, Nature, 351, 644-647.

O'Nions, R. K., M. Frank, F. von Blanckenburg, and H. F. Ling (1998), Secular variation of $\mathrm{Nd}$ and $\mathrm{Pb}$ isotopes in ferromanganese crusts from the Atlantic, Indian, and Pacific oceans, Earth Planet. Sci. Lett., 155, 15-28.

Otto-Bliesner, B. L., E. C. Brady, and C. Shields (2002), Late Cretaceous ocean: Coupled simulations with the National Center for Atmospheric Research Climate System Model, J. Geophys. Res., 107(D2), 4019, doi:10.1029/2001JD000821.

Pak, D. K., and J. P. Kennett (2002), A foraminiferal isotopic proxy for upper water mass stratification, J. Foraminiferal Res., 32, 319-327.

Pearson, P. N., P. W. Ditchfield, J. Singano, K. G. Harcourt-Brown, C. J. Nicholas, R. K. Olsson, N. M. Shackleton, and M. A. Hall (2001), Warm tropical sea surface temperatures in the Late Cretaceous and Eocene epochs, Nature, 413, 481-487.

Perch-Nielsen, K. (1985), Mesozoic calcareous nannofossils, in Plankton Stratigraphy, edited by H. M. Bolli, J. B. Saunders, and K. Perch- Nielsen, pp. 329-426, Cambridge Univ. Press, New York.

Pettke, T., A. N. Halliday, and D. K. Rea (2002), Cenozoic evolution of Asian climate and sources of Pacific seawater $\mathrm{Pb}$ and $\mathrm{Nd}$ derived from eolian dust of sediment core LL44-GPC3, $\mathrm{Pa}$ leoceanography, 17(3), 1031, doi:10.1029/2001PA000673.

Piepgras, D. J., and S. B. Jacobsen (1988), The isotopic composition of neodymium in the North Pacific, Geochim. Cosmochim. Acta, $52,1373-1381$.

Premoli Silva, I., and W. V. Sliter (1994), Cretaceous planktonic foraminiferal biostratigraphy and evolutionary trends from the Bottaccione Section, Gubbio, Italy, Palaeontogr. Ital., 82, 2-90.

Premoli Silva, I., and W. V. Sliter (1999), Cretaceous paleoceanography: Evidence from planktonic foraminiferal evolution, in Evolution of the Cretaceous Ocean-Climate System, edited by E. Barrera and C. C. Johnson, Spec. Pap. Geol. Soc. Am., 332, 301-328.
Schmidt, G. A., and L. A. Mysak (1996), Can increased poleward oceanic heat flux explain the warm Cretaceous climate?, Paleoceanography, 11, 579-593.

Schrag, D. P., D. J. DePaolo, and F. M. Richter (1995), Reconstructing past sea surface temperatures: Correcting for diagenesis of bulk marine carbonate, Geochim. Cosmochim. Acta, 59, 2265-2278.

Shackleton, N. J., M. A. Hall, and A. Boersma (1984), Oxygen and carbon isotope data from Leg 74 foraminifers, Initial Rep. Deep Sea Drill. Proj., 74, 599-612.

Sholkovitz, E. R. (1993), The geochemistry of rare earth elements in the Amazon River estuary, Geochim. Cosmochim. Acta, 58, 2181-2190.

Sissingh, W. (1977), Biostratigraphy of Cretaceous calcareous nannoplankton, Geol. Mijnbouw, 57, 433-440.

Sliter, W. V. (1989), Biostratigraphic zonation for Cretaceous planktonic foraminifers examined in thin section, J. Foraminiferal Res., 19, 1-19.

Stille, P., M. Steinmann, and S. R. Riggs (1996), Nd isotope evidence for the evolution of the paleocurrents in the Atlantic and Tethys Oceans during the past $180 \mathrm{Ma}$, Earth Planet. Sci. Lett., 144, 9-19.

Stout, L. N., et al. (1981), Site 465: Southern Hess Rise, Proc. Ocean Drill. Program Initial Rep., 62, 199-292.

Tachikawa, K., C. Jeandel, and M. Roy-Barman (1999), A new approach to the $\mathrm{Nd}$ residence time in the ocean: The role of atmospheric inputs, Earth Planet. Sci. Lett., 170, 433-446.

Tanaka, T., et al. (2000), JNdi-1: A neodymium isotopic reference in consistency with La Jolla neodymium, Chem. Geol., 168, 279-281.

Thierstein, H. R. (1979), Paleoceanographic implications of organic carbon and carbonate distribution in Mesozoic deep sea sediments, in Deep Drilling Results in the Atlantic Ocean: Continental Margins and Paleoenvironment, Maurice Ewing Ser., vol. 3, edited by M. Talwani, W. Hay, and W. B. F. Ryan, pp. 249-274, AGU, Washington, D. C.

Thomas, D. J. (2004), Evidence for production of North Pacific deep waters during the early Cenozoic warm interval, Nature, $430,65-68$.

Thomas, E., and A. J. Gooday (1996), Cenozoic deep-sea foraminifers: Tracers for changes in oceanic productivity?, Geology, 24, 355-358.

Widmark, J. G. V. (1995), Multiple deep-water sources and trophic regimes in the latest Cretaceous deep sea: Evidence from benthic foraminifer, Mar. Micropaleontol., 26, 361-384.

Wilson, P. A., and B. N. Opdyke (1996), Equatorial sea-surface temperatures for the Maastrichtian revealed through remarkable preservation of metastable carbonate, Geology, 24, 555-558.

Wilson, P. A., H. C. Jenkyns, H. Elderfield, and R. L. Larson (1998), The paradox of drowned carbonate platforms and the origin of Cretaceous Pacific Guyots, Nature, 392, 889-894.

Zachos, J. C., M. A. Arthur, T. J. Bralower, and H. J. Spero (2002), Palaeoclimatology (Communication arising): Tropical temperatures in greenhouse episodes, Nature, 419, 897-898. 